\title{
Pengembangan Computer Assisted Instructional Integrated Science Materi "Hujan” di Sekolah Dasar
}

\author{
Setria Utama Rizal1, Din Azwar Uswatun², Astri Sutisnawati², Rifki Aditia² \\ 1IAIN Palangka Raya, setria.utama.rizal@iain-palangkaraya.ac.id \\ 2Universitas Muhammadiyah Sukabumi, dinazwar@ummi.ac.id, \\ astri212@ummi.ac.id, rifki93@gmail.com
}

\begin{abstract}
ABSTRAK
Minimnya media pembelajaran menjadi salah satu indikator pembelajaran IPA kurang disukai siswa Sekolah Dasar. Penggunaan media pembelajaran dapat mengatasi kesulitan siswa dalam memahami materis secara kontekstual. Penelitian ini bertujuan menghasilkan produk media pembelajaran Computer Assisted Instructional integrated science materi "hujan" dalam meningkatkan keterampilan berpikir kritis siswa kelas III SD. Metode penelitian ini menggunakan research \& development dengan model pengembangan Borg \& Gall dan uji coba lapangan menggunakan one-group pretest-postest design di SDIT Al-Khoiriyah Al-Husna Sukabumi. Teknik pengambilan data menggunakan metode wawancara, observasi, angket, dan tes. Instrumen pengambilan data meliputi pedoman wawancara, lembar observasi, lembar angket, dan soal tes. Hasil penelitian ini berupa produk media pembelajaran Computer Assisted Instructional integrated science SD dengan materi "hujan". Hasil validasi produk menunjukkan bahwa media pembelajaran Computer Assisted Instructional integrated ini layak digunakan dalam pembelajaran IPA SD dengan rata-rata penilaian dari validator kategori "Sangat Baik". Hasil uji coba lapangan menunjukkan bahwa Media pembelajaran Computer Assisted Instructional integrated science SD dengan materi "hujan" efektif digunakan dalam proses pembelajaran IPA SD untuk meningkatkan critical thinking skills siswa dengan gain sebesar 0,81. Sehingga hasil penelitian ini dapat digunakan dalam proses pembelajaran IPA pada siswa SDIT Al-Khoiriyah Al-Husna Sukabumi dan dikembangkan pada SD/MI lain.
\end{abstract}

Kata Kunci: Pembelajaran Berbantuan Komputer, Integrasi IPA SD

\begin{abstract}
The lack of learning media is one indicator of science learning less favored by elementary school students. The use of instructional media can overcome students' difficulties in understanding contextually material. The purpose of this research is to produce integrated learning media Computer Assisted Instructional learning material "rain" material in improving critical thinking skills of third grade elementary school students. This research method uses research \& development with the Borg \& Gall development model and field trials using one-group pretest-posttest design at SDIT Al-Khoiriyah Al-Husna Sukabumi. Data collection techniques using interviews, observation, questionnaires, and tests. Data collection instruments included interview guidelines, observation sheets, questionnaire sheets, and test questions. The results of this study are in the form of learning products for Computer Assisted
\end{abstract}


Instructional integrated science elementary school with "rain" material. The results of the product validation show that the integrated Computer Assisted Instructional learning media is appropriate for use in elementary science learning with an average rating from the "Very Good" category validator. Field trial results show that the integrated Computer Assisted Instructional elementary school learning media with "rain" material is effectively used in the elementary science learning process to improve students' critical thinking skills with a gain of 0.81 . So that the results of this study can be used in the learning process of science in students of SDIT Al-Khoiriyah Al-Husna Sukabumi and developed in other SD / MI.

Keywords: Computer Assisted Instructional, Integrated Science SD

Article History:

Received: $13-07-2020$

Revised: $18-07-2020$

Accepted: 19-07-2020

Copyright (C) Rizal, Uswatun, Sutisnawati, Aditia

\section{PENDAHULUAN}

Studi OECD/PISA tahun 2018 menunjukkan bahwa siswa Indonesia pandai dalam mencari informasi, mengevaluasi, dan merefleksi informasi, tetapi lemah dalam memahami informasi serta skor ratarata siswa Indonesia mencapai 389 dengan skor rata-rata OECD yakni 489 (Kemendikbud.go.id, 2019). Berdasarkan data di atas menunjukan pencapaian prestasi belajar siswa Indonesia di bidang sains masih rendah dan belum menekankan memahami informasi.

Pembelajaran IPA di Sekolah Dasar sangat erat interaksi antara siswa dengan lingkungan (Sugiarti \& Handayani, 2017). Selain itu, mata pelajaran IPA di Sekolah Dasar kurang disukai siswa karena dianggap sulit 44
(Uswatun et al., 2016). Guru belum menggunakan media yang menarik sehingga banyaknya materi yang harus diingat dan dihafalkan menimbulkan kejenuhan pada siswa serta belum mengaitkannya dengan lingkungan sekitar anak (Jelita. et al., 2020; Ningsih, 2012).

Media pembelajaran merupakan suatu teknologi pembawa pesan, membangkitkan motivasi dan rangsangan kegiatan belajar mengajar sehingga dapat mencapai tujuan pembelajaran yang akan dicapai (Rizal, et al., 2016; Kustandi \& Sutjipto, 2013; Rusman, 2012; Arsyad, 2011).

Computer Assisted Instructional dapat menciptakan lingkungan belajar dan meningkatkan kemampuan siswa (Septiyono \& Maureen, 2015; Setiyadi, 
2016). Pendapat tersebut diperkuat oleh (Hernawan et al., 2008) menyatakan Computer Assisted Instructional bertujuan untuk menyediakan suasana (lingkungan) yang memberikan fasilitas belajar untk meningkatkan kemampuan siswa. Oleh karena itu, diperlukan cara pembelajaran yang dapat menyiapkan peserta didik untuk mencapai literasi IPA dan teknologi, mampu berpikir logis, kritis, kreatif serta dapat berargumentasi secara benar.

Keterampilan berpikir kritis merupakan salah satu keterampilan berpikir dalam sains. Berpikir kritis membentuk pengetahuan, alasan, keterampilan, sikap, dan analisis perkembangan ilmu pengetahuan dan tekonolgi ((Ennis, 1993; Paul \& Elder, 2006; Pradana et al., 2017)

Penelitian ini bertujuan untuk mengembangkan Computer Assisted Instructional integrated science materi "hujan" sehingga dapat meningkatkan keterampilan berpikir kritis siswa kelas III SDIT Al-Khoiriyah Al-Husna Sukabumi.

\section{METODE}

Metode yang digunakan dalam Penelitian Computer Assisted
Instructional integrated science materi "hujan" di SD merupakan research \& development yang menggunakan model pengembangan Borg \& Gall.

Subjek penelitian ini adalah siswa sekolah dasar kelas III SDIT AlKhoiriyah Al-Husna Sukabumi. Siswa semester genap yang terlibat berjumlah 14 anak sebagai subjek uji coba produk media Computer Assisted Instructional integrated science $\mathrm{SD}$ dengan materi "hujan" yang menjadi subjek uji coba lapangan pendahuluan dan uji coba lapangan utama. Teknik pengumpulan data menggunakan instrumen pedoman wawancara, lembar observasi, lembar angket, dan soal tes.

\section{HASIL PENELITIAN DAN PEMBAHASAN}

\section{A. Studi Pendahuluan}

Studi lapangan berdasarkan hasil wawancara dengan guru kelas III diperoleh informasi bahwa proses pembelajaran IPA masih membutuhkan media pembelajaran yang inovatif. Selain itu, menurut guru materi IPA tema-tema di sekolah dasar tersebut sudah disampaikan secara terpadu tapi belum megintegrasikan nilai-nilai keislaman walaupun di Sekolah Dasar Islam 
Terpadu. Sedangkan IPA merupakan ilmu yang mempelajari tentang gejala alam terintegrasi nilai Islam akan terbangun teori yang kuat, saling melengkapi, dan mengkonfirmasi (Susilowati, 2017).

\section{B. Perencanaan Penelitian}

Perumusan struktur isi Kompetensi Dasar IPA kelas III SD yang menjadi acuan pada pengembangan materi "Hujan" adalah 6.3 Mendeskripsikan pengaruh cuaca bagi kegiatan manusia. Kegiatan siswa pada materi "Hujan" mencari tahu tentang siklus air melalui peristiwa hujan yang disimulasikan di dalam media Computer Assisted Instructional. Pada tema ini dintegrasikan dengan konsep IPA yang lain yaitu: perubahan wujud zat, (2) pergerakan air, dan (3) sifat air melarutkan zat.

Perumusan tujuan berdasarkan indikator pencapaian KD yang diintegrasikan dengan indikator keterampilan berpikir kritis. Tujuan pembelajaran memuat audience, behaviour, condition, dan degree yaitu melalui penyajian simulasi hujan siswa dapat (1) menghubungkan peran komponen pada siklus hujan dengan komponen pada simulasi hujan, (2) menganalisis perubahan wujud yang terjadi pada peristiwa hujan, dan (3) menyimpulkan dampak pergerakan air yang bermanfaat dan merugikan.

\section{Pengembangan Produk Awal}

Penyusunan bentuk awal Computer Assisted Instructional telah disesuaikan dengan format. Selanjutnya draft awal produk divalidasi oleh ahli dan praktisi. Adapun ilustrasi tampilan media adalah sebagai berikut:

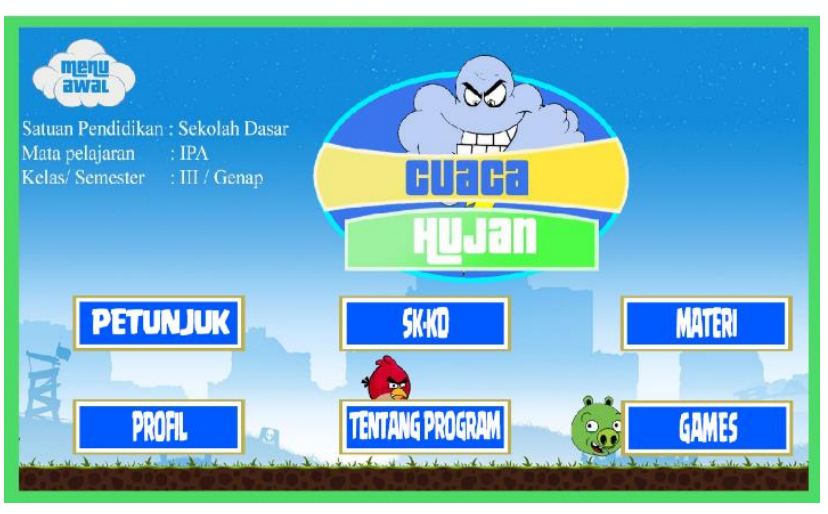

Gambar 1. Menu utama media

Draft awal Computer Assisted Instructional selanjutnya dilakukan proses validasi oleh empat orang ahli, terdiri dua orang ahli (dosen) dan dua orang praktisi (guru SD). Hal ini sesuai pendapat (Azimi et al., 2017) bahwa media pembelajaran hasil pengembangan minimal divalidasi oleh tiga orang validator yang terdiri dari 1 orang validator ahli, dan 2 orang praktisi.

Hasil validasi kemudian dianalisis untuk memperbaiki draf 
sebelum ujicoba. Skor penilaian kelayakan media pembelajaran dari validator kemudian dirata-rata.

\begin{tabular}{|c|c|c|c|c|c|}
\hline \multirow[t]{2}{*}{ Aspek } & \multicolumn{2}{|c|}{$\begin{array}{c}\text { Skor } \\
\text { Dosen }\end{array}$} & \multirow[t]{2}{*}{$\begin{array}{c}\text { Rerata } \\
\text { Skor }\end{array}$} & \multirow[t]{2}{*}{$\begin{array}{l}\text { Skor } \\
\text { Maks }\end{array}$} & \multirow[t]{2}{*}{$\begin{array}{c}\text { Katego } \\
\text { ri }\end{array}$} \\
\hline & I & II & & & \\
\hline $\begin{array}{l}\text { Kelaya } \\
\text { kan isi }\end{array}$ & 14 & 15 & 14,5 & 16 & $\begin{array}{c}\text { Sangat } \\
\text { Baik }\end{array}$ \\
\hline $\begin{array}{l}\text { Bahasa } \\
\text { dan } \\
\text { gambar }\end{array}$ & 15 & 13 & 14,0 & 16 & $\begin{array}{c}\text { Sangat } \\
\text { Baik }\end{array}$ \\
\hline $\begin{array}{c}\text { Penyaji } \\
\text { an }\end{array}$ & 15 & 16 & 15,5 & 20 & Baik \\
\hline $\begin{array}{c}\text { Kegrafi } \\
\text { san }\end{array}$ & 13 & 15 & 14,0 & 16 & $\begin{array}{c}\text { Sangat } \\
\text { Baik }\end{array}$ \\
\hline Audio & 11 & 9 & 10,0 & 12 & $\begin{array}{c}\text { Sangat } \\
\text { Baik }\end{array}$ \\
\hline
\end{tabular}

Tabel 2. Hasil Penilaian Produk Oleh Guru

\begin{tabular}{|c|c|c|c|c|c|}
\hline \multirow[t]{2}{*}{ Aspek } & \multicolumn{2}{|c|}{$\begin{array}{l}\text { Skor } \\
\text { Guru }\end{array}$} & \multirow[t]{2}{*}{$\begin{array}{c}\text { Rerata } \\
\text { Skor }\end{array}$} & \multirow[t]{2}{*}{$\begin{array}{l}\text { Skor } \\
\text { Maks }\end{array}$} & \multirow[t]{2}{*}{$\begin{array}{c}\text { Katego } \\
\text { ri }\end{array}$} \\
\hline & I & II & & & \\
\hline $\begin{array}{l}\text { Kelaya } \\
\text { kan isi }\end{array}$ & 13 & 15 & 14,0 & 16 & $\begin{array}{c}\text { Sangat } \\
\text { Baik }\end{array}$ \\
\hline $\begin{array}{c}\text { Bahasa } \\
\text { dan } \\
\text { gamba } \\
r\end{array}$ & 13 & 16 & 14,5 & 16 & $\begin{array}{c}\text { Sangat } \\
\text { Baik }\end{array}$ \\
\hline $\begin{array}{c}\text { Penyaji } \\
\text { an }\end{array}$ & 14 & 18 & 16,0 & 20 & Baik \\
\hline $\begin{array}{c}\text { Kegrafi } \\
\text { san }\end{array}$ & 11 & 12 & 11,5 & 16 & Baik \\
\hline Audio & 10 & 111 & 10,5 & 12 & $\begin{array}{c}\text { Sangat } \\
\text { Baik }\end{array}$ \\
\hline
\end{tabular}

\section{Komponen}

media

pembelajaran yang divalidasi oleh dua dosen ahli dan dua guru SD meliputi aspek kelayakan isi, bahasa dan gambar, penyajian, kegrafisan, dan audio. Berdasarkan hasil validasi dapat diketahui bahwa penilaian ahli dan praktisi rata-rata "Sangat Baik". Hasil ini berarti masing-masing komponen media pembelajaran Computer Assisted Instructional yang dikembangkan layak digunakan dalam proses pembelajaran setelah direvisi sesuai dengan saran dan masukan dari validator.

\section{Ujicoba Lapangan Pendahuluan}

Uji coba lapangan pendahuluan bertujuan untuk mengetahui apakah media pembelajaran Computer Assisted Instructional hasil pengembangan dapat mengatasi permasalahan keterampilan berpikir kritis siswa yang masih rendah. Berdasarkan hasil uji coba lapangan pendahuluan diketahui bahwa siswa masih kesulitan menjawab pertanyaan-pertanyaan keterampilan berpikir kritis. Sejalan dengan pendapat (Kartimi \& Lilliasari, 2012) yang menyatakan berpikir kritis merupakan suatu sikap yang cenderung untuk mempertimbangkan dan memikirkan suatu masalah yang timbul dari pengalaman. Namun demikian, siswa terlihat antusias dan termotivasi selama mengikuti pembelajaran menggunakan media pembelajaran Computer Assisted Instructional serta mempunyai pengalaman baru. Penggunaan multimedia sebagai salah satu sumber 
belajar non cetak dapat memprovokasi perubahan secara radikal dalam proses pembelajaran dari metode pembelajaran secara tradisional (siswa pasif) ke "siswa aktif" (Alimah, 2012).

Uji coba lapangan pendahuluan ditemukan beberapa kelemahan produk media pembelajaran Computer Assisted Instructional diantaranya: 1) terdapat kata-kata yang asing bagi siswa, 2) ukuran huruf yang kurang besar untuk siswa yang duduk di belakang atau mata minus, 3) ilustrasi gambar yang kurang jelas, scene games yang belum mengembangkan keterampilan berpikir kritis siswa, dan 4) Belum menginternalisasi Nilai AlIslam dalam media. Kelemahankelemahan yang ditemukan pada uji coba lapangan pendahuluan ini dijadikan bahan evaluasi dan revisi produk.

\section{E. Revisi Produk}

Kegiatan revisi dilakukan baik terhadap konten maupun tampilan yang bertujuan untuk menyempurnakan produk perangkat pembelajaran IPA. Revisi pada penelitian ini dilakukan sebanyak tiga kali yaitu berdasarkan (1) masukan dan saran dari validator, kekurangan dan kelemahan saat uji coba lapangan pendahuluan, dan (3) hasil evaluasi pada saat uji coba luas. Saran masukan digunakan untuk memperbaiki produk sehingga menghasilkan media pembelajaran Computer Assisted Instructional yang layak digunakan dalam proses pembelajaran. Berikut hasil revisi pada penelitian ini yang disajikan pada Gambar 3 s.d. Gambar 6.

Masukan: Belum menginternalisasi Nilai Al-Islam dalam media Computer Assisted Instructional

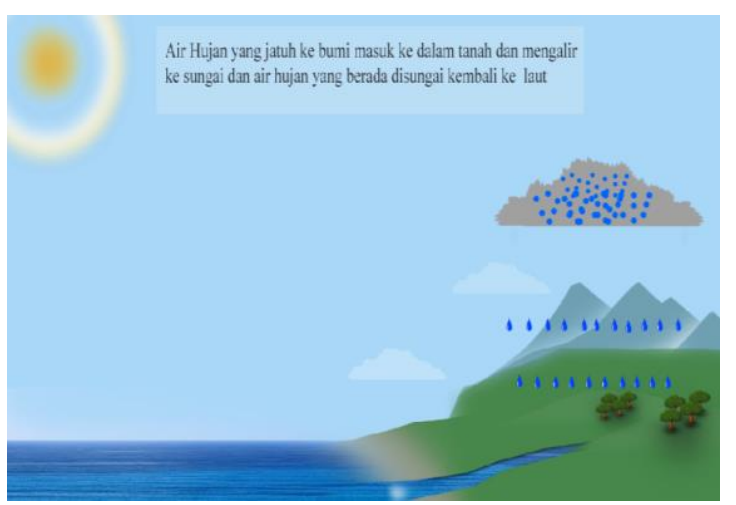

Gambar 3.

Tampilan peristiwa hujan sebelum direvisi

Revisi: Ditambahkan Ayat Al-Quran kedalam materi yang sesuai

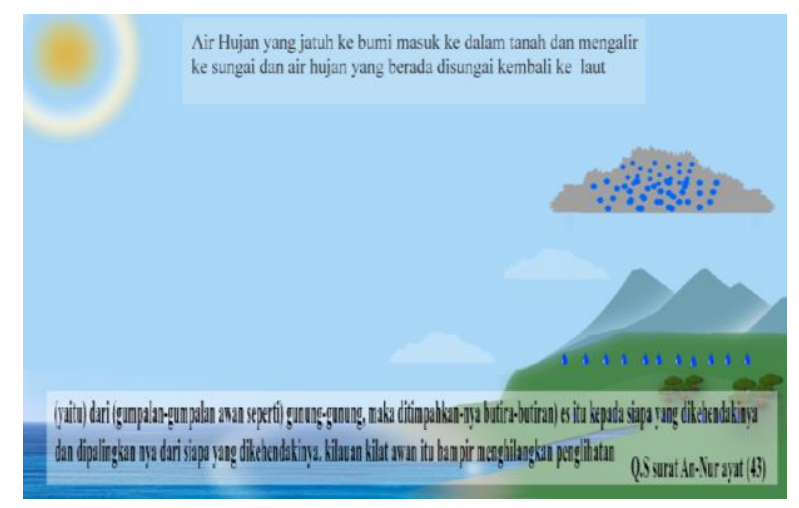

Gambar 4. 
Tampilan peristiwa hujan setelah direvisi

Keterampilan berpikir kritis siswa akan semakin terasah bahwa hujan turun atas kehendak Allah dan dibuktikan dengan adanya ayat suci Al-Qur'an. Hal ini diperkuat hasil penelitian (Susilowati, 2017) bahan ajar IPA terintegrasi nilai Islam dapat meningkatkan sikap religi dengan kriteria tinggi, sikap positif terhadap IPA dengan kriteria sedang, dan prestasi belajar IPA dengan kriteria sedang.

Masukan: Games Puzzle belum mengembangkan keterampilan berpikir kritis

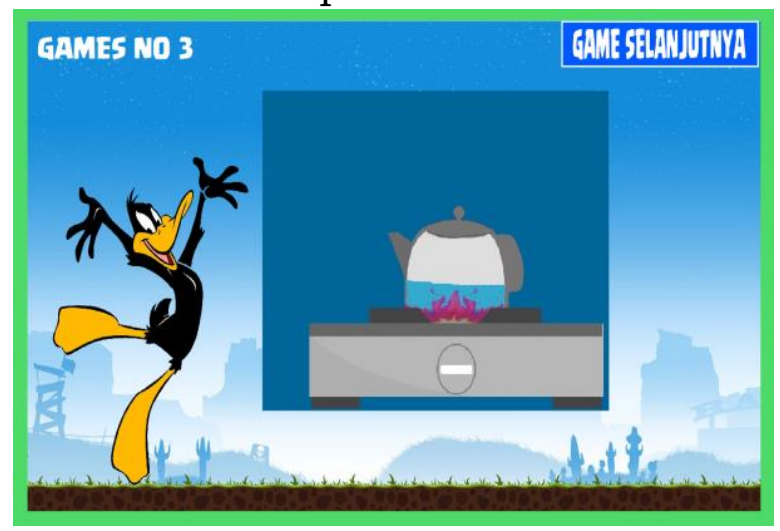

Gambar 5.

Tampilan games sebelum direvisi

Revisi: Games ditambahkan pertanyaan-pertanyaan keterampilan berpikir kritis

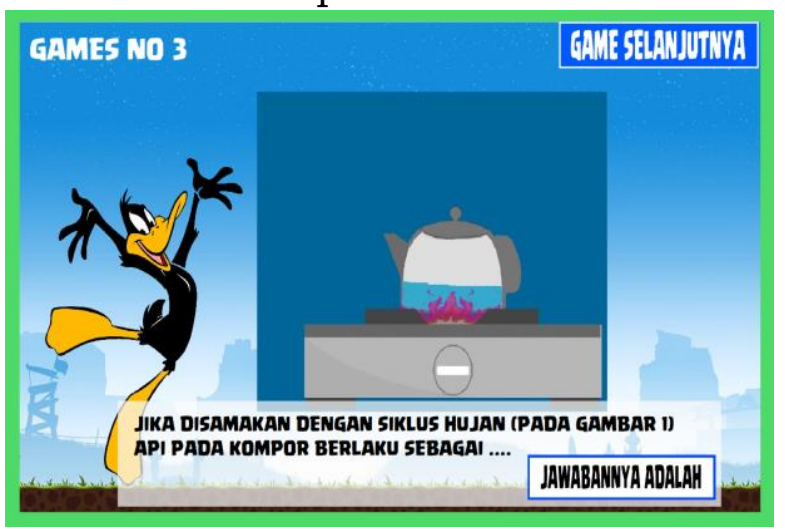

Gambar 6.

Tampilan games setelah direvisi
Berdasarkan hasil validasi ahli dan praktisi diperoleh rekomendasi bahwa produk media Computer Assisted Instructional hasil pengembangan layak digunakan untuk ujicoba lapangan. Data yang diperoleh dari uji coba pendahuluan lapangan kemudian dianalisis dan dievaluasi untuk memperbaiki produk. Hasil revisi ini kemudian digunakan untuk uji coba lapangan luas.

\section{F. Uji Coba Lapangan}

Setelah media pembelajaran Computer Assisted Instructional dinyatakan valid oleh validator, selanjutnya dilakukan uji coba lapangan dengan desain eksperimen one-group pretest-posttest design. Ujicoba lapangan menggunakan media pembelajaran Computer Assisted Instructional hasil revisi atas masukan dan saran dari validator. Ujicoba lapangan pada penelitian ini dilakukan sebanyak dua kali, yaitu: 1) Uji Coba Lapangan pendahuluan dan 2) Uji Coba Lapangan Luas. Uji coba lapangan luas menggunakan media pembelajaran Computer Assisted Instructional hasil revisi II berdasarkan evaluasi pada saat uji coba lapangan pendahuluan. Uji coba lapangan luas 
ini bertujuan untuk mengetahui efektifitas produk dalam meningkatkan keterampilan berpikir kritis sebelum (pretest) dan setelah (posttest) mengikuti kegiatan pembelajaran menggunakan media pembelajaran Computer Assisted Instructional hasil pengembangan. Uji coba ini dilakukan pada satu kelas yaitu Kelas III SDIT Al-Khoiriyah A1Husna yang terdiri dari 14 siswa. Selama implementasi produk hasil pengembangan dilakukan pengukuran keterampilan berpikir kritis siswa melalui pertanyaan yang terdapat pada games di media Computer Assisted Instructional. Peningkatan keterampilan berpikir kritis siswa diketahui dari rata-rata nilai pretest dan postest. Hasil analisis ini ditunjukkan oleh grafik pada Gambar berikut.

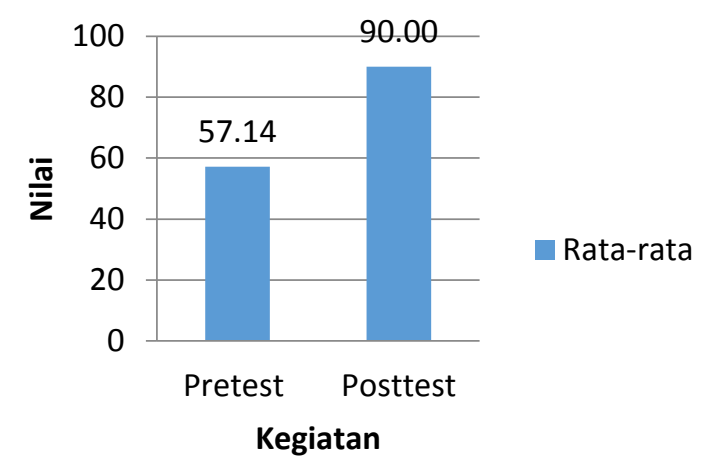

Gambar 7.

Grafik Rerata Nilai Keterampilan Berpikir Kritis Siswa
Data keterampilan berpikir kritis siswa diperoleh dari tes sebelum menggunakan media pembelajaran Computer Assisted Instructional (pretest) dan setelah pembelajaran menggunakan media pembelajaran Computer Assisted Instructional (posttest). Peningkatan keterampilan berpikir kritis siswa diketahui melalui menghitung selisih antara skor posttest dan skor pretest dengan menggunakan rumus gain score. Berdasarkan hasil perhitungan dan analisis data, terdapat peningkatan skor pretest dan skor posttest. Secara keseluruhan rata-rata skor pretest yang diperoleh siswa yaitu 57,14 dan rata-rata skor posttest 90,00. Berdasarkan rata-rata skor pretest dan posttest didapatkan peningkatan keterampilan berpikir kritis siswa dengan gain score sebesar 0,81 termasuk dalam kriteria "Tinggi".

Peningkatan keterampilan berpikir kritis siswa ini dikarenakan pada kondisi awal (pretest) siswa belum mengalami pembelajaran secara langsung bagaimana peristiwa hujan terjadi. Dengan adanya media pembelajaran Computer Assisted Instructional yang dilengkapi dengan simulasi peristiwa hujan maka memungkinkan siswa mempejalari 
suatu kompetensi secara runtut dan sistematis sehingga secara akumulatif mampu menguasai tujuan pembelajaran secara utuh dan terpadu. Hal ini sesuai peneleitian (Fitriani et al., 2013) media pembelajaran, melatih peserta didik belajar mandiri, membiasakan berpikir kritis dan kreatif, menarik perhatian dan sebagai alat simulasi materi pelajaran yang efisien dan efektif yang melibatkan peserta didik secara langsung.

Media pembelajaran Computer Assisted Instructional ini dilengkapi dengan scene games yang menarik dan memotivasi siswa. Games yang dicantumkan yaitu jenis games puzzle, setelah gambar terbuka secara utuh maka muncul pertanyaan-pertanyaan yang yang melatih siswa berpikir kritis. Dengan demikian media pembelajaran Computer Assisted Instructional ini efektif digunakan dalam pembelajaran. Diharapkan, media pembelajaran Computer Assisted Instructional hasil pengembangan berdampak positif dengan meningkatkan keterampilan berpikir kritis siswa.

\section{IV.KESIMPULAN}

Pengembangan media Computer Assisted Instructional dinilai layak oleh validator dan dapat diimplementasikan dalam menunjang proses pembelajaran, serta efektif digunakan dalam proses pembelajaran IPA sekolah dasar untuk meningkatkan critical thinking skills siswa dengan gain sebesar 0,81.

\section{DAFTAR PUSTAKA}

Alimah, S. (2012). Jurnal Pendidikan IPA Indonesia. Jurnal Pendidikan IPA Indonesia, 1(2), 131-140. https://journal.unnes.ac.id/nju/i ndex.php/jpii/article/view/5792/ 4726

Azimi, A., Rusilowati, A., \& Sulhadi, S. (2017). Pengembangan Media Pembelajaran IPA Berbasis Literasi Sains untuk Siswa Sekolah Dasar. PSEJ (Pancasakti Science Education Journal), 2(2), 145.

https://doi.org/10.24905/psej.v2 i2. 754

Ennis, R. H. (1993). Critical Thinking Assessment. Theory Into Practise, 32(3), 179-186. http:/ /www.jarwancenter.com/download/enniscritical-thinking-assessment-pdf Fitriani, F. H., Parmin, \& Akhlis, I. (2013). Pengembangan Media Pembelajaran Ipa Terpadu Berbasis Komputer Pada Tema Bunyi Melalui Lesson Study Untuk Kelas Viii. USEJ - Unnes Science Education Journal, 2(2). https://doi.org/10.15294/usej.v2 i2. 2042

Jelita., Suzana, Y., \& Nuraida. (2020). 
PENINGKATAN AKTIVITAS

BELAJAR SISWA DALAM

PEMBELAJARAN IPA MELALUI

LESSON STUDY Jelita $1^{*}$, Yenny

Suzana 2 , Nuraida 12 . JIPI

(Jurnal IPA Dan Pembelajaran IPA, 4(1), 81-91.

https://doi.org/10.24815/jipi.v4i 1.16392

Kartimi, \& Lilliasari. (2012). Jurnal

Pendidikan IPA Indonesia. Jurnal Pendidikan IPA Indonesia, 1(1), 21-26.

Kemendikbud.go.id. (2019). Hasil PISA Indonesia 2018: Akses

Makin Meluas, Saatnya

Tingkatkan Kualitas. 4 Desember 2019.

https://www.kemdikbud.go.id/m ain/blog/2019/12/hasil-pisaindonesia-2018-akses-makinmeluas-saatnya-tingkatkankualitas\#: :text=Hasil studi PISA 2018 yang,rata skor OECD yakni 487.

Ningsih. (2012). PENINGKATAN

HASIL BELAJAR IPA MELALUI

PENGGUNAAN MEDIA

PEMBELAJARAN INTERAKTIF DI

KELAS V Ningsih PGSD-FIP

Universitas Negeri Jakarta

IMPROVEMENT OF LEARNING

OUTCOMES IN SCIENCE

UTILIZING. Perspektif Ilmu

Pendidikan, Vol. 25(Th. XVI), 120.

Paul, R., \& Elder, L. (2006). Critical

Thinking Concepts and Tools. In

Performance + Instruction (pp. 1-

21). www.criticalthinking.org

Pradana, S. D. S., Parno, P., \&

Handayanto, S. K. (2017).

Pengembangan tes kemampuan

berpikir kritis pada materi Optik

Geometri untuk mahasiswa

Fisika. Jurnal Penelitian Dan

Evaluasi Pendidikan, 21(1), 51.

https://doi.org/10.21831/pep.v2

1i1.13139
Septiyono, E., \& Maureen, I. Y.

(2015). Pengembangan Cai Ipa

Perkembangbiakan Ovipar Untuk

Siswa Kelas Vi Mi Al-Aziez

Surabaya. Jurnal Mahasiswa

Teknologi Pendidikan, 2015(6), 2.

Setiyadi, D. (2016). Media

Pembelajaran untuk Anak

Sekolah Dasar Tentang

Pengenalan Tata Surya

Menggunakan Metode Computer

Assisted Instruction (CAI).

Information Management for

Educators and Professionals, 1(1), 42-53.

Sugiarti, L., \& Handayani, D. E.

(2017). Pengembangan Media

Pokari Pokabu (Pop-Up dan Kartu

Ajaib Pengelompokkan

Tumbuhan) Untuk Siswa Kelas III SD/MI. Al Ibtida: Jurnal

Pendidikan Guru MI, 4(1), 109.

https://doi.org/10.24235/al.ibtid a.snj.v4i1.1475

Susilowati, S. (2017). Pengembangan

Bahan Ajar IPA Terintegrasi Nilai

Islam untuk Meningkatkan Sikap dan Prestasi Belajar IPA Siswa. Jurnal Inovasi Pendidikan IPA, 3(1), 78.

https://doi.org/10.21831/jipi.v3i 1.13677

Uswatun, D. A., Rizal, S. U., Sutisnawati, A., Aditia, R., \& Nurasiah, I. (2016). IMPLEMENTASI COMPUTER ASSISTED INSTRUCTIONAL MODEL GAMES PADA INTEGRATED SCIENCE DI SD. UMMI (Jurnal Penelitian Dan Pengembangan Sains Dan Teknologi, 10(3), 77-83. https://jurnal.ummi.ac.id/index. php/ummi/article/view/318 